\title{
New host record of a 'Candidatus Phytoplasma asteris'-related strain infecting peach in India
}

\author{
Jitender Singh • Anchal Rani • Pankaj Kumar • \\ V. K. Baranwal • P. L. Saroj • Anil Sirohi • \\ Amar N. Pandey • Peer M. Schenk
}

Received: 3 October 2012 / Accepted: 28 January 2014 / Published online: 16 February 2014

(C) Australasian Plant Pathology Society Inc. 2014

\begin{abstract}
Phytoplasma-like symptoms such as general decline, leaf reddening, yellowing, shortening of internodes and witches broom were observed in peach trees in the orchards of Meerut, India during May-August 2010-13. Leaf samples from symptomatic peach trees were collected and the presence of phytoplasma was confirmed by amplification of the 16S rRNA gene and $\sec A$ gene by phytoplasma specific primers. Sequencing and BLAST analysis of $\sim 1.25 \mathrm{~kb}$ of the $16 \mathrm{~S}$ rDNA gene and $\sim 840$ bp of non-ribosomal secA gene fragments indicated that phytoplasma associated with peach disease was identical to the $16 \mathrm{SrI}$ Aster yellows group phytoplasma. Phylogenetic analysis of $16 \mathrm{~S}$ rDNA peach phytoplasma also grouped it with 16SrI-A. This is the first report of association of a phytoplasma of 16SrI-A subgroup with peach trees in India.
\end{abstract}

J. Singh $(\bowtie) \cdot$ A. Rani $\cdot$ P. Kumar $\cdot$ A. Sirohi

College of Biotechnology, Sardar Vallabhbhai Patel University of

Agriculture and Technology, Meerut 250110, India

e-mail: jeets_80@rediffmail.com

V. K. Baranwal

Plant Virology Unit, Division of Plant Pathology, Indian Agricultural

Research Institute, New Delhi, India 110012

P. L. Saroj

Indian Council of Agricultural Research, Division of Horticulture,

KAB-II, New Delhi 110 012, India

J. Singh $\cdot$ A. N. Pandey $\cdot$ P. M. Schenk

School of Agriculture and Food Sciences, The University of

Queensland, Brisbane, QLD 4072, Australia
Keywords BLAST · PCR · Phytoplasma P Prunus persica . Witches broom

In India, peach (Prunus persica) is mostly grown in the subtropical region of Uttar Pradesh and neighbouring states. During May 2010-13, symptoms of general decline, leaf reddening, yellowing, shortening of internodes, and witches broom (Fig. 1) were observed in about $40 \%$ of the trees in the peach orchards near Sardar Vallabhbhai Patel University of Agriculture and Technology, Meerut in Uttar Pradesh State of India. Remaining trees appeared healthy showing vigorous growth throughout the year. Therefore, a study was undertaken to determine the presence of a phytoplasma in symptomatic and non-symptomatic peach trees. Several groups of phytoplasmas are known to be associated with peach diseases worldwide (Poggi Pollini et al. 1993; Marcone et al. 1996; Blomquist and Kirkpatrick 2002; Anfoka and Fattash 2004; Zunnoon-Khan et al. 2010; Arocha-Rosete et al. 2011). Identification of the phytoplasma associated with this peach disease was carried out by amplifying and sequencing the $\sec A$ gene and 16S rRNA gene.

Total DNA was extracted from leaf midribs of 30 trees in three replicates each (symptomatic and non symptomatic) with DNeasy Plant Mini Kit, Qiagen, Germany. A nested PCR assay to amplify the phytoplasma $16 \mathrm{~S}$ rRNA gene using universal phytoplasma primers P1/P7 (Deng and Hiruki 1991), R16F2/R16R2 (Gundersen and Lee 1996) and P1/Tint (Smart et al. 1996) was carried out. The characteristic bands of desired size (1.8, 1.26 and $1.6 \mathrm{~kb}$, respectively) were obtained in twelve out of the thirty trees tested 

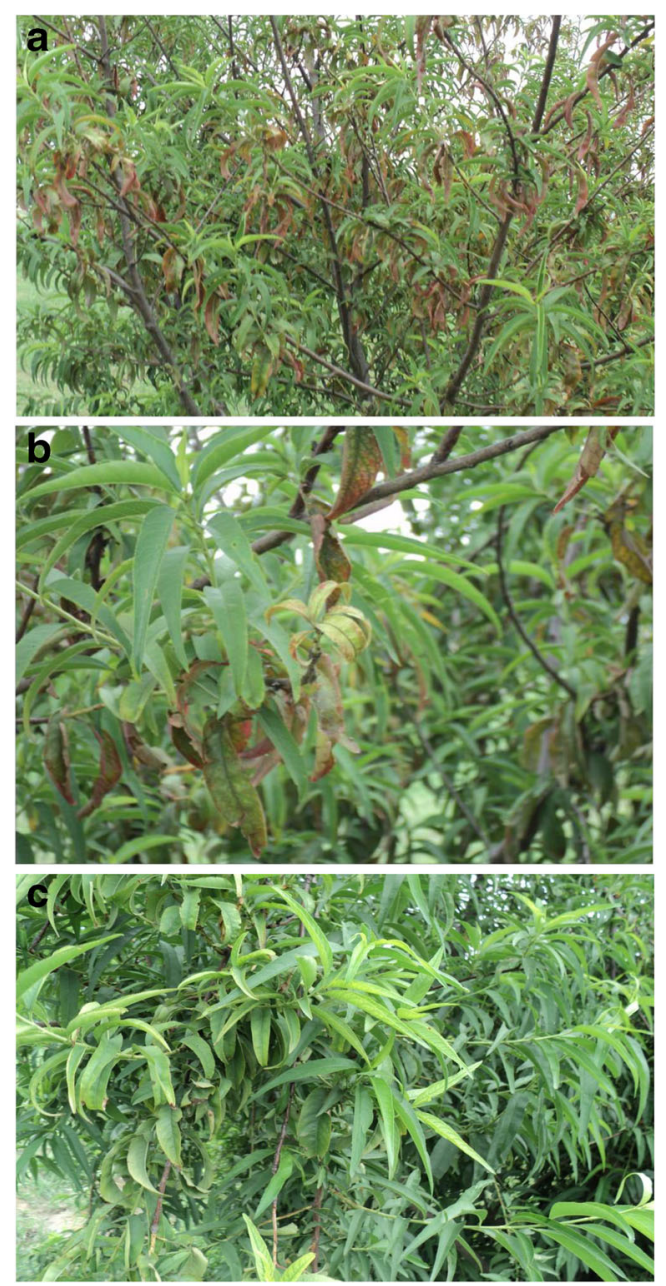

Fig. 1 Symptoms of phytoplasma disease infecting peach trees. $\mathbf{a}$ and $\mathbf{b}$; Typical symptoms of phytoplasmal disease in the peach orchards of Meerut, India. Symptoms include leaf reddening, rosette-type appearance similar to witches broom. $\mathbf{c}$ Healthy peach trees

for the presence of phytoplasmas from symptom-bearing trees. The twelve positive trees were further tested for phytoplasma with primers $\sec A 1 \mathrm{~F} / \sec A 3 \mathrm{R}$ of non-ribosomal secA gene (Hodgetts et al. 2008) and bands of $\sim 840 \mathrm{bp}$ were observed. However, there was no phytoplasma detected in symptomless trees. Three PCR products amplified with $\mathrm{P} 1 /$ Tint samples and three from $\sec A 1 \mathrm{~F} / \sec A 3 \mathrm{R}$ were selected and purified (QIAquick Gel Extraction kit, Qiagen, Germany) and directly sequenced at Bioserve Pvt Limited, Hyderabad. A resultant 1,592 bp $16 \mathrm{~S}$ rDNA sequence with Accession No. AB858361 and 482 bp secA gene sequence AB858360 was deposited in DNA Data Bank of Japan (http://www.ddbj.nig.ac.jp/). Blastn analysis of the 16S rDNA gene sequences revealed that the peach phytoplasma was $99 \%$ identical to phytoplasmas in the aster yellows phytoplasma group (16SrI group). Similarly, Blastn analysis of the secA gene sequences also confirmed that the phytoplasma was 95-99\% identical to phytoplasmas in the aster yellows phytoplasma group (16SrI).

Phylogenetic analysis was performed by constructing an evolutionary tree using MEGA version 4.0 (Tamura et al. 2007) using sequences from earlier reported phytoplasmas (Fig. 2). Sequences were aligned by Clustral X (Thompson et al. 1997) and trimmed to the length of the phytoplasma sequences being analysed in the present study. Maximum parsimony method was used for tracing evolutionary relationships. The out group chosen for rooting was Acholeplasma palmae (M23932). On comparison with $16 \mathrm{~S}$ rDNA sequences of phytoplasma groups and subgroups associated with different plant/trees species peach phytoplasma (AB858361) clustered with the 16SrI 'Candidatus Phytoplasma asteris' group.

Sequence similarity matrices generated for $16 \mathrm{~s}$ rRNA gene using Bioedit (Hall 1999) ranged between 89-99 \%. Phylogenetic analysis supported BLAST comparisons, showing the similarity of the phytoplasma associated with peach disease (AB858361) to subgroup 16SrI-A by clustering in the single distinct branch that encompasses this subgroup.

Our study confirmed a new host recording of $16 \mathrm{SrI}$ aster yellows phytoplasma (AY) group with peach disease in India. The 16SrI group phytoplasma has been associated with several phytoplasma diseases in India such as Periwinkle virescence (Azadvar and Baranwal 2009), Sandal spike (Khan et al. 2008), Sesamum phyllody (Khan et al. 2007), Parthenium viresence (Raj et al., 2008b), Achyranthesaspera yellows (Raj et al. 2008c), Little leaf disease of desert rose (Raj et al. 2006a), witches-broom disease of Cannabis sativa (Raj et al. 2008a), Pigeon pea little leaf (Raj et al. 2006b), Chilli little leaf (Khan and Raj 2005), witches-broom of Crotalaria tetragona (Baiswar et al. 2009) and Black pepper phyllody (Bhat et al. 2006). These results highlight to the diversity of phytoplasma found in peach previously well documented. The molecular identification and characterisation of peach disease should contribute to expanding the knowledge of the genetic diversity and epidemiology of $16 \mathrm{SrI}$ phytoplasmas in 
Fig. 2 A phylogenetic tree based on the $16 \mathrm{~S}$ ribosomal gene using the Maximum Parsimony method. The percentage of replicate trees in which the associated taxa clustered together in the bootstrap test (1,000 replicates) are shown next to the branches. The tree is drawn to scale, with branch lengths calculated using the average pathway method (Nei and Kumar 2000) and are in the units of the number of changes over the whole sequence. ' $\mathrm{Ca}$. P' stands for 'Candidatus Phytoplasma sp.'; P stands for 'Phytoplasma'; A laidlawii stands for Acholeplasma laidlawii as the outgroup

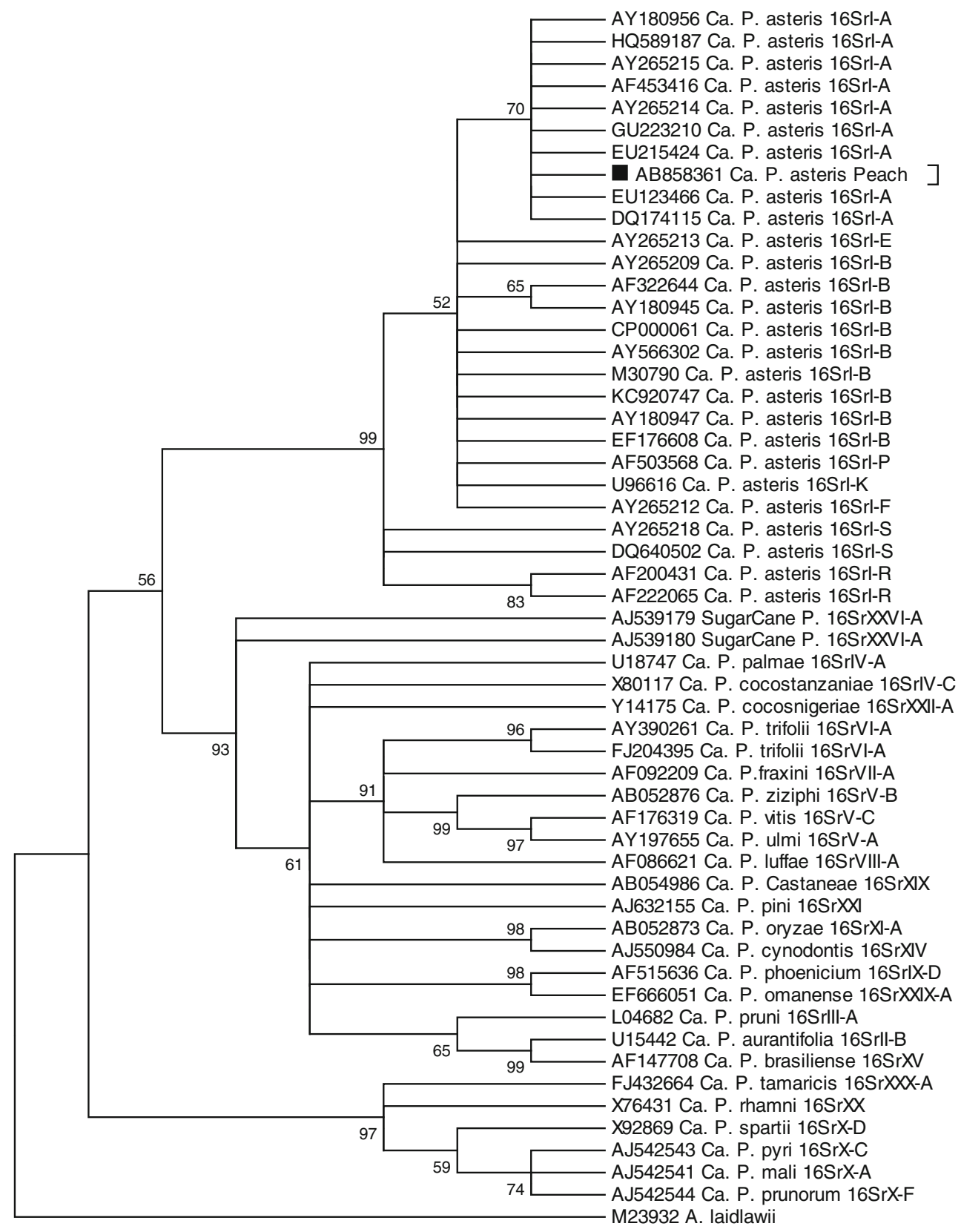

which could assist in developing effective disease management strategies.

Acknowledgments The authors acknowledge the Vice Chancellor, Sardar Vallabhbhai Patel University of Agriculture and Technology, Meerut-250110, Uttar Pradesh, Council of Science and Technology, Uttar Pradesh and Bioinformatics facility (DBT funded), India, for providing financial support and the facilities to carry out this research work. 


\section{References}

Anfoka GH, Fattash I (2004) Detection and identification of aster yellows (16SrI) phytoplasma in peach trees in Jordan by RFLP analysis of PCR-amplified products (16S rDNAs). J Phytopathol 152:210-214

Arocha-Rosete Y, Zunnoon-Khan S, Iryna K, Crosby W, Scott J, Bertaccini A, Michelutti R (2011) Identification and molecular characterization of the phytoplasma associated with peach rosettelike disease at the Canadian Clonal Genebank based on the 16S rRNA gene analysis. Can J Plant Pathol 33:127-134

Azadvar M, Baranwal VK (2009) Detection and identification of phytoplasma associated with proliferation and virescence disease of periwinkle (Catharanthus roseus) in New Delhi, India. In: Proc 5th international conference on plant pathology in the globalized era, 10-13 Nov 2009. New Delhi, India, pp 287

Baiswar P, Arocha Y, Chandra S, Ngachan SV (2009) First report of 'Candidatus Phytoplasma asteris' associated with witches'-broom of Crotalaria tetragona in India. New Dis Rep 19:17

Bhat AI, Madhubala R, Hareesh PS, Anandaraj M (2006) Detection and characterization of the phytoplasma associated with a phyllody disease of black pepper (Piper nigrum L.) in India. Scientia Horticulturae 107:200-204

Blomquist CL, Kirkpatrick BC (2002) Identification of phytoplasma taxa and insect vectors of peach yellow leaf roll disease in California. Plant Dis 86:759-63

Deng S, Hiruki C (1991) Genetic relatedness between two nonculturable mycoplasmalike organisms revealed by nucleic acid hybridization and polymerase chain reaction. Phytopathology 81:1475-1479

Gundersen DE, Lee IM (1996) Ultrasensitive detection of phytoplasmas by nested-PCR assays using two universal primer pairs. Phytopathologia Mediterranea 35:144-151

Hall TA (1999) BioEdit: a user-friendly biological sequence alignment editor and analysis program for windows 95/98/NT. Nucleic Acids Symp Ser 41:95-98

Hodgetts J, Boonham N, Mumford R, Harrison N, Dickinson M (2008) Phytoplasma phylogenetics based on analysis of secA and $23 \mathrm{~S}$ rRNA gene sequences for improved resolution of candidate species of 'Candidatus Phytoplasma'. Int J Syst Evol Microbiol 58(8): 1826-1837

Khan MS, Raj SK (2005) First report of molecular detection of an Aster yellows phytoplasma ('Candidatus Phytoplasma asteris') isolate infecting chilli (Capsicum annuum) in India. New Dis Rep 13:10
Khan MS, Raj SK, Snehi SK (2007) First report of 'Candidatus phytoplasma asteris' affecting sesame cultivation in India. J Plant Pathol 89:301-305

Khan JA, Singh SK, Ahmad J (2008) Characterisation and phylogeny of a phytoplasma inducing sandal spike disease in sandal (Santalum album). Ann Appl Biol 153:365-372

Marcone C, Ragozzino A, Seemüller E (1996) European stone fruit yellows phytoplasma as the cause of peach vein enlargement and other yellows and decline diseases of stone fruits in southern Italy. J Phytopathol 144:11-12

Poggi Pollini C, Giunchedi L, Gambin E (1993) Presence of mycoplasma like organisms in peach trees in Northern- central Italy. Phytopathol Mediterr 32:188-192

Raj SK, Khan MS, Kumar S, Snehi SK (2006a) Association of 'Candidatus Phytoplasma asteris' with little leaf disease of desert rose. New Dis Rep 14:5

Raj SK, Khan MS, Snehi SK, Srivastava S, Singh HB (2006b) First report of a 'Candidatus Phytoplasma asteris' isolate associated with a little leaf disease of pigeon pea in India. Plant Pathol 55:823

Raj SK, Snehi SK, Kumar S (2008a) 'Candidatus Phytoplasma asteris' (group 16SrI) associated with a witches'-broom disease of Cannabis sativa in India. Plant Pathol 57:1173-1173

Raj SK, Khan MS, Snehi SK, Kumar S, Mall S, Rao GP (2008b) First report of phytoplasma 'Candidatus phytoplasma asteris' (16SrI) from Parthenium hysterophorus L. showing symptoms of virescence and witches'-broom in India. Aust Plant Dis Notes 3:44-45

Raj SK, Snehi SK, Kumar S, Pratap D, Khan MS (2008c) Association of 'Candidatus Phytoplasma asteris' (16SrI group) with yellows of Achyranthes aspera in India. New Dis Rep 18:12

Smart CD, Schneider B, Blomquist CL, Guerra LJ, Harrison NA, Ahrens U, Lorenz KH, Seemüller E, Kirkpatrick BC (1996) Phytoplasmaspecific PCR primers based on sequences of the 16S-23S rRNA spacer region. Appl Environ Microbiol 62:2988-2993

Tamura K, Dudley J, Nei M, Kumar S (2007) MEGA 4.0: Molecular Evolutionary Genetics Analysis (MEGA) software version 4.0. Mol Biol Evol 24:1596-1599

Thompson JD, Gibson TJ, Plewniak F, Jeanmougin F, Higgins DG (1997) The ClustalX windows interface: flexible strategies for multiple sequence alignment aided by quality analysis tools. Nucleic Acids Research 24:4876-4882

Zunnoon-Khan S, Arocha-Rosete Y, Scott J, Crosby W, Bertaccini A, Michelutti R (2010) First report of 'Candidatus Phytoplasma fraxini' (group 16SrVII phytoplasma) associated with a peach disease in Canada. New Dis Rep 21:20 